\title{
BDS 570 Kapsamında Verilen Denetçi Raporlarının İletişim Değeri Açısından İncelenmesi \\ (Examination of the Auditor's Reports Given in the Scope of BDS 570 in Terms of Communication Value)
}

\author{
Alpaslan YAŞAR iD a Eray ÇETIN ID b \\ a Adana Alparslan Türkeş Bilim ve Teknoloji Üniversitesi, Adana, Türkiye. ayasar@atu.edu.tr \\ b Osmaniye Korkut Ata Üniversitesi, Osmaniye, Türkiye. eraycetin@osmaniye.edu.tr
}

\begin{tabular}{|c|c|}
\hline MAKALE BİLGİSİ & ÖZET \\
\hline $\begin{array}{l}\text { Anahtar Kelimeler: } \\
\text { BDS } 570\end{array}$ & $\begin{array}{l}\text { Amaç - Bu çalışmanın amacı, işletmenin sürekliliğine ilişkin önemli belirsizlik vurgusu } \\
\text { yapılan denetçi raporlarının iletişim değerini BDS } 570 \text { kapsamında değerlendirmektir. }\end{array}$ \\
\hline $\begin{array}{l}\text { Bağımsız denetçi raporu } \\
\text { Bağımsız denetçi raporunun iletişim } \\
\text { değeri }\end{array}$ & $\begin{array}{l}\text { Yöntem - Bu kapsamda, Borsa İstanbul'da } 2018 \text { yılında işlem gören mali sektör şirketleri } \\
\text { dışındaki şirketlerin denetçi raporları BDS } 570 \text { kapsamında içerik analizi yöntemiyle } \\
\text { incelenmiştir. }\end{array}$ \\
\hline Şeffaflık & $\begin{array}{l}\text { Bulgular - Araştırma bulguları, BDS } 570 \text { kapsamındaki hususların denetçi raporlarında, söz } \\
\text { konusu standarda uygun bölüm başlığ1 altında verilmeyip, farklı bölüm veya başlıklar }\end{array}$ \\
\hline Revizyon Tarihi 31 Ocak 2020 & \\
\hline
\end{tabular}

Kabul Tarihi 10 Şubat 2020

Tartışma - Bu durum, şeffaflı̆̆ ve buna bağlı olarak da denetçi raporunun iletişim değerini zayıflatabilecek bir durum olarak değerlendirilmiştir.

Makale Kategorisi:

Araştırma Makalesi

\begin{tabular}{|c|c|}
\hline ARTICLE INFO & ABSTRACT \\
\hline Keywords: & Purpose - The purpose of this study is to evaluate the communication value of the auditor \\
\hline ISA 570 & reports under BDS 570, which emphasizes significant uncertainty regarding the continuity \\
\hline Auditor report & of the enterprise. \\
\hline $\begin{array}{l}\text { Communication value of auditor's } \\
\text { report } \\
\text { Transparency }\end{array}$ & $\begin{array}{l}\text { Design/methodology/approach - In this context, the auditor reports of companies other } \\
\text { than the financial sector companies traded on Borsa Istanbul in } 2018 \text { were analyzed by } \\
\text { content analysis method within the scope of BDS } 570 \text {. }\end{array}$ \\
\hline $\begin{array}{l}\text { Received } 30 \text { November } 2019 \\
\text { Revised } 31 \text { January } 2020\end{array}$ & $\begin{array}{l}\text { Findings - The findings of the research showed that the issues within the scope of BDS } 570 \\
\text { are not presented in the auditor reports under the heading of the appropriate section in the } \\
\text { relevant standard, but under different sections or headings. }\end{array}$ \\
\hline Article Classification: & $\begin{array}{l}\text { Discussion - This situation is considered as a situation that may undermine the } \\
\text { transparency and consequently the communication value of the auditor's report. }\end{array}$ \\
\hline
\end{tabular}

\section{Giriş}

Uluslararası Denetim ve Güvence Standartları Kurulu (IAASB)'nun denetimde şeffaflı̆̆ı ve kaliteyi sağlamaya yönelik olarak yeni ve revize denetim standartları yayınlamasına bağlı olarak, Türkiye dahil bir çok ülkede denetim standartlarında benzer düzenlemeler yapılmıştır. Bu kapsamda, Türkiye'de BDS 701 Kilit Denetim Konuları Standardı yayınlanmış ve BDS 260, BDS 570, BDS 700, BDS 705, BDS 706 denetim standartlarının ise son sürümleri yayınlanmıştır.

Bu çalışmanın amacı, işletmenin sürekliliğine ilişkin önemli belirsizlik vurgusu yapılan denetçi raporlarını BDS 570 İşletmenin Sürekliliği Standardı kapsamında incelemek suretiyle, söz konusu denetim raporlarının iletişim değerini değerlendirmektir. Bu amaçla, Borsa İstanbul (BIST)'da 2018 yılında işlem gören mali sektör

\section{Önerilen Atıf/Suggested Citation}

Yaşar, A., Çetin, E. (2020). BDS 570 Kapsamında Verilen Denetçi Raporlarının İletişim Değeri Açısından İncelenmesi, Işsletme Araştırmaları Dergisi, 12 (1), 384-391. 


\section{A. Yaşar - E. Çetin 12/1 (2020) 384-391}

şirketleri dışındaki 268 şirketin bağımsız denetim raporları incelenerek, BDS 570 kapsamında işletmenin sürekliliğine ilişkin belirsizlik vurgusu yapılan 21 şirket belirlenmiştir. Örneklemdeki söz konusu 21 denetim raporunun 6' sında olumlu görüş; 15'inde ise sınırlı olumlu (şartlı) görüş verildiği tespit edilmiştir. Söz konusu raporlar üzerinde yapılan inceleme sonucunda elde edilen bulgular; sektör, denetim görüşü, denetim kuruluşu ve açıklanma biçimi yönünden Tablolarda sınıflandırılmıştır. Elde edilen bulgular; BDS 570 kapsamındaki hususların denetçi raporlarında, söz konusu standarda uygun bölüm başlığı altında verilmeyip, farklı bölüm veya başlıklar altında verilmesinin şeffaflığı ve buna bağlı olarak da denetçi raporunun iletişim değerini zayıflatabileceği şeklinde değerlendirilmiştir.

Bu çerçevede; ikinci bölümde, denetçi raporlarının iletişim değerine ilişkin kısa açılama yapılmıştır. Üçüncü bölümde, işletmenin sürekliliği esasının BDS 570 kapsamında denetçi raporu üzerindeki etkileri belirtilmiştir. Araştırmanın yöntemine dördüncü bölümde, araştırma bulgularına beşinci bölümde yer verilmiştir. Son bölümde ise, çalışmanın sonuçları belirtilmiştir.

\section{Denetçi Raporlarının İletişim Değeri}

Denetçi raporlarında açıklanan hususların denetim sonuçlarını şeffaf bir şekilde yansıtması, denetçi raporlarının iletişim değerini arttırmak suretiyle bilgi kullanıcılarının kararlarını olumlu yönde etkileyebilmektedir. Bu durum, denetçi raporlarının mevcut biçim ve içeriklerinde bazı değişikliklerin yapılmasını zorunlu kılmıştır. Buna bağlı olarak, ABD başta olmak üzere, ülkemiz dahil bir çok ülkede denetim sonuçlarının raporlanmasına ilişkin ilaveler ve/veya değişiklikler yapılmaktadır.

Uluslararası Denetim ve Güvence Standartları Kurulu (IAASB) 2013 Haziran toplantısında yeni bir standart olarak ISA 701 (Kilit Denetim Konuları)'i ve revize edilmiş 5 standardın (ISA 260, ISA 570, ISA 700, ISA 705 ve ISA 706) taslak halini oybirliği ile kabul etmiştir. Ocak 2015'te ise, 15 Aralık 2016'da sona eren dönemlerden itibaren uygulanmak üzere, denetim raporlarının yararlılığını ve kullanışlılığını arttırmak için yeni ve revize edilmiş denetim standartları yayınlanmıştır (Sarısoy ve Kepçe, 2019: 46-48). Benzer şekilde, Türkiye'de de söz konusu standartlar kapsamında düzenlemeler yapılmıştır. Denetim raporunun biçim ve içeriğinde yapılan söz konusu önemli değişiklikler ve kilit denetim konularına denetim raporlarında yer verilmesinde, denetçi ile bilgi kullanıcıları arasındaki iletişimin arttıılması ve dolayısıyla denetimde şeffaflık ve kalitenin arttırılması hedeflenmiştir (Kavut ve Güngör, 2018: 60; Karacan ve Uygun, 2018: 633).

\section{3. İşletmenin Sürekliliği Esasının BDS 570 Kapsamında Denetçi Raporu Üzerindeki Etkileri}

Bilindiği üzere BDS 570 İşletmenin Sürekliliği Standardının ilk sürümü 23.01.2014'te, son sürümü ise 24.03.2017' de yayımlanmıştır. Söz konusu denetim standardının son sürümü, şeffaflığın ve denetçi raporunun iletişim değerinin arttırılmasına yönelik düzenlemelerin bir uzantısıdır. Buna bağlı olarak, sürekliliğe ilişkin önemli belirsizliklerin denetçi raporuna etkileri ve denetçi sorumlulukları düzenlenmiştir.

BDS 570'e göre; finansal tabloların işletmenin sürekliliği esasına göre hazırlanmış olması ancak yönetimin işletmenin sürekliliği esasını kullanmasının denetçi görüşüne göre uygun olmaması durumunda denetçi olumsuz görüş verir (BDS 570, md. 21).

Finansal tablolarda önemli belirsizliğe ilişkin yeterli açıklamanın yapılması durumunda denetçi, olumlu görüş verir ve denetçi raporunda "İşletmenin Sürekliliği ile İlgili Önemli Belirsizlik" başlığı altında ayrı bir bölüme yer verir (BDS 570, md. 22)1. Bu husus, denetçi raporunun iletişim değeri açısından önem taşımaktadır. Nitekim, BDS 570'in 28. Paragrafında, bu hususun önemi şu şekilde açıklanmıştır: “Önemli bir belirsizliğin saptanması, kullanıcıların finansal tabloları anlamaları açısından önem arz etmektedir. İşletmenin sürekliliğine ilişkin önemli bir belirsizliğin mevcut olduğunu gösteren ayrı başlıklı bir bölüme yer verilmesi, bu durum hakkında kullanıcıları uyarır." Bu şekilde ayrı bir başlık altında açıklama, denetçi raporunun iletişim değerini ve dolayısıyla şeffaflığı arttıracaktır. Finansal tablolarda önemli belirsizliğe ilişkin yeterli açıklamanın yapılmaması durumunda ise denetçi, BDS 705 (Bağımsız Denetçi Raporunda Olumlu Görüş Dışında Bir Görüş Verilmesi) uyarınca sınırlı olumlu görüş (şartlı görüş) veya olumsuz görüşten uygun olanı verir. Bu durumda, denetçi raporunun Sınırlı Olumlu (veya Olumsuz) Görüşün Dayanağı bölümünde,

\footnotetext{
${ }^{1}$ BDS 570'in önceki sürümünde (BDS 570, md. 19) ise, işletmenin sürekliliği varsayımını kullanmanın uygun olduğu ancak önemli bir belirsizliğin varlığı ve finansal tablolarda yeterli açıklama yapılması durumunda; denetçinin, olumlu denetim görüşü vermesi ve raporuna "Dikkat Çekilen Hususlar" paragrafı eklemesi gerekmekteydi.
} 


\section{A. Yaşar - E. Çetin 12/1 (2020) 384-391}

işletmenin sürekliliğini devam ettirmesine ilişkin önemli belirsizliğin olduğunu ve finansal tablolarda bu hususun yeterince açılanmadığını belirtir (BDS 570, md. 23).

\section{Literatür Taraması}

Literatürde, işletmenin sürekliliğine ile ilgili nicel ve nitel çeşitli çalışmalar bulunmakla birlikte, BDS 570 denetim standardının son sürümü ile ilişkili sınırlı sayıda çalışma olduğu görülmektedir. Bu kapsamda, çalışma konusu ile ilgili literatüre ilişkin özet bilgilere aşağıda yer verilmiştir:

Citron ve Taffler (1992); işletmenin sürekliliğine ilişkin belirsizlik durumunda denetim raporunun değerini incelemişlerdir. İngiltere halka açık şirketlerinin 1977-1986 dönemine ilişkin verileri, lojit yöntemi ile analiz edilmiştir. Çalışma sonuçları, finansal başarısızlık ihtimali çok yüksek olmadığı sürece, sürekliliğe ilişkin belirsizlik yönündeki denetim görüşü ihtimalinin çok düşük olduğunu göstermiştir. Ayrıca, çalışma bulguları, sürekliliğe ilişkin belirsizliğin varlığı ve denetçi değişikliği arasındaki ilişkiyi desteklemiştir.

Uzay ve Tanç (2009); 2000-2008 yılları arasında, İMKB' de işlem görüp işlem sırası kapanan ve faaliyetlerinde belirsizlikler olan şirketlerin bağımsız denetim raporlarını incelemek suretiyle, işletmenin sürekliliği kavramına ilişkin açıklamalarda bulunulup bulunulmadığını araştırmışlardır. Çalışma sonuçları, özellikle 2000-2007 yılları arasında süreklilikleri tehlikeye girmesine rağmen bazı işletmelerin "olumlu görüş" bildirilen bağımsız denetim raporlarına sahip olduklarını göstermiştir. Ayrıca, uluslararası denetim standartlarının yaygın olarak uygulanmaya başlanmasıyla, denetim raporlarında da sürekliliğe ilişkin açılamaların daha fazla yer aldığı tespit edilmiştir.

Sayar ve Ergüden (2016); 15 Aralık 2016 tarihinde veya sonrasında sona erecek dönemler için hazırlanacak finansal tablolar hakkındaki değişecek denetçi raporlarının içeriğinin neler olacağını ve hangi hususların değişeceğini çalışmalarına konu almışlardır. Çalışmada, yeni denetim raporunda işletmenin sürekliliği varsayımının daha da ön plâna çıktığı, finansal tablo dipnotlarına daha fazla odaklanıldığı, mesleki şüphecilikte yoğunlaşmanın ön plâna çıtı̆̆g ve kilit denetim alanlarının değerlendirildiği belirtilmiştir.

Türel ve Türel (2016); Uluslararası Denetim ve Güvence Standartları Kurulu (IAASB) tarafından denetim raporları ile ilgili yapılan yeni düzenlemeler tanıtılmış ve finansal iletişime olacak etkileri tartışılmıştır. Çalışmada, yapılan yeni düzenlemelerin denetçinin işletmenin sürekliliği gibi önemli denetim alanlarına daha fazla odaklanmasını gerektirdiği, denetçinin mesleki şüpheciliğini ve sonuç olarak denetim kalitesini arttırmasının beklendiği, süreklilikle ilgili açıklamalara ve denetim raporunda referans verilecek olan önemli finansal tablo açıklamalarına karşı artacak ilginin finansal raporlama kalitesini de olumlu yönde etki etmesinin beklendiği belirtilmiştir. Çalışmada, ayrıca, yeni denetim raporlarının sadece yatırımcı taleplerine cevap vermediği, finansal raporlamaya yönelik kamuoyu güvenini artırmada büyük fırsatlar sunduğu yönünde değerlendirmelerde bulunulmuştur.

Yanık ve Karataş (2017); yeni denetim raporlaması ve Uluslararası Denetim Standartları (UDS)'nın güncellenmesine duyulan ihtiyacın nedenlerini irdelemişlerdir. Ayrıca, güncellenen UDS 700 ve yeni yayımlanan UDS 701 kapsamında denetçi raporlarındaki yenilikler ve kilit denetim konularını açıklamışlar ve ülke uygulamalarına da yer verilmek suretiyle eski ve yeni denetçi raporları arasındaki farklılık ve benzerlikleri ortaya koymuşlardır.

Akdoğan vd., (2018); Türkiye'deki denetim piyasasının dağılımını ve olumlu görüş ve olumlu görüş dışında görüş oluşturulurken denetim kuruluşları tarafından önem verilen hususları açıklamış ve tartışmaya açmışlardır. Çalışmada, Borsa İstanbul'da 2014-2016 yılları arasında işlem gören 511 şirketin denetim raporlarındaki görüşlerin nasıl oluştuğu incelenmiştir. Araştırmanın bulguları; istisnaları olmakla birlikte, denetim raporlarının genel olarak BDS 570 "İşletmenin Sürekliliği" ve BDS 700 "Finansal Tablolara İlişkin Görüş Oluşturma ve Raporlama" standartları ile uyum içinde hazırlandığını göstermiştir. Araştırmada, işletmenin sürekliliği, alacakların tahsilatı ile ilgili yaşanan belirsizlikler ve ortaklık ve ilişkili taraflarla olan işlemlerin olumlu görüş dışında görüş verilen raporlara sıkça dayanak teşkil ettiği gözlenmiştir. Araştırmanın diğer bir bulgusu ise, bazı durumlarda denetim şirketlerinin olumsuz görüş yerine şartlı görüş, şartlı görüş yerine olumlu görüş vermeyi tercih ettiği yönünde gerçekleşmiştir.

Çil Koçyiğit vd., (2018); Borsa İstanbul imalat sektöründeki şirketlerin 01.01.2016-31.12.2016 dönemine ait bağımsız denetçi raporlarını BDS 570 ve BDS 700'e uygunluk yönünden doküman analizi tekniği ile 
incelemişlerdir. Araştırmanın sonuçları, bağımsız denetçi raporlarının çoğunlukla BDS 570 ve BDS 700 çerçevesinde ve söz konusu standartlara uygun bir şekilde düzenlendiği, küçük bir kısmında ise mevcut standartlar ile uyumsuzluklar olduğu tespit edilmiştir.

Yılmaz ve Yaşar (2018); işletmenin sürekliliği varsayımına ilişkin şüphe oluşturabilecek olay veya şartların neler olduğunu ve hangi tür denetim görüşleri ile hangi denetim kuruluşlarınca verildiğini araştırmışlardır. Çalışmada, Borsa İstanbul imalat sanayii şirketlerinin 2013-2016 yıllarına ait denetim raporları içerik analizi yöntemiyle incelenmiştir. Çalışma sonuçları, işletmenin sürekliliğine ilişkin şüphe oluşturabilecek en sık karşılaşılan olay veya şartın, 'önemli tutarlardaki faaliyet zararı veya nakit akışı oluşturan varlıkların değerindeki önemli azalışlar' olduğunu göstermiştir. Ayrıca, bu tür olay veya şartların en çok 'Dikkat Çekilen Hususlar' paragrafı içeren olumlu görüş raporu ile verildiği, bu tür denetim görüşlerinin en çok 4 büyükler, en az ise ulusal denetim firmalarınca verildiği bulgusu elde edilmiştir.

Taş vd., (2018); işletmelerin sürekliliğe ilişkin açıklamalarına bağımsız denetim raporlarında yer verilmesinin işletme yönetimi ile yatırımcı açısından önemini ve bağımsız denetim raporlarında sürekliliğin ne şekilde işlenmesi gerektiğini incelemişlerdir. Bu kapsamda, BDS 570'in bağımsız denetim raporlarına etkisini ve önemini analiz etmişlerdir. Çalışma bulguları, incelenen işletmelerin bağımsız denetim raporlarında süreklilik varsayımına yeterince açıklama getirmediği saptanmıştır. Ayrıca, süreklilik kavramına uygun denetçi görüşünün verilmediği örneklere rastlandığı belirtilmiştir.

Demirkol (2019); BDS 570 İşletmenin Sürekliliği standardının uygulama süreci ve bağımsız denetim raporlarına etkisi incelenmiştir. Çalışma, Borsa İstanbul'da 2013-2017 yılları arasında işlem gören inşaat ve bayındırlık sektörü şirketlerine ait bağımsız denetim raporları üzerinden gerçekleştirilmiştir. Çalışmada, bağımsız denetçinin işletmenin sürekliliği yeteneğini etkileyecek durumları tespit ve bildirmesinde izleyeceği süreç, şekil üzerinde somutlaştırılmıştır. Çalışmada elde edilen bulgular, örneklem kapsamındaki sektör şirketlerine ait bağımsız denetim raporlarının büyük bir çoğunluğunda BDS 570 standardı ile ilgili bilginin yer almadığı tespit edilmiştir.

\section{Araştırmanın Yöntemi}

İşletmenin sürekliliğine ilişkin önemli belirsizlik vurgusu yapılan denetçi raporlarının BDS 570 kapsamında 2018 yılı için içerik analizi yöntemiyle incelendiği bu çalışmada; aşağıdaki gibi bir yöntem takip edilmiştir:

> Borsa İstanbul (BİST)'de 2018 yılında işlem gören şirketlerden mali sektör dışındaki şirketler belirlenmiştir.

> 2018 yılı bağımsız denetim raporunda işletmenin sürekliliğine ilişkin önemli belirsizlik vurgusu yapılan şirketler tespit edilmiştir.

> Örneklemdeki şirketlerin denetçi raporları BDS 570 kapsamında içerik analizi yöntemiyle incelenerek, bu kapsamdaki denetim raporlarının iletişim değerine ilişkin değerlendirmeler yapılmıştır.

\section{1. Örneklem Seçimi}

Araştırmanın ana kütlesi Borsa İstanbul (BİST)'da 2018 yılında işlem gören mali sektör şirketleri dışındaki 268 şirketten oluşmaktadır. Araştırma konusu kapsamında, işletmenin sürekliliğine ilişkin belirsizlik vurgusu yapılan 21 şirket araştırmanın örneklemini oluşturmaktadır. Örneklemdeki sürekliliğe ilişkin belirsizlik vurgusu yapılan 21 denetim raporunun 6'sı olumlu görüş; 15'i ise sinırlı olumlu (şartl1) görüş türünde verilmiştir. Araştırmada, Borsa İstanbul Kamuoyu Aydınlatma Platformu web sayfasındaki bağımsız denetim raporları kullanılmıştır.

\subsection{Veri Analiz Yöntemi}

İşletmenin sürekliliğine ilişkin önemli belirsizlik vurgusu yapılan denetçi raporları BDS 570 kapsamında incelenerek, söz konusu denetim raporlarının iletişim değerinin değerlendirildiği bu çalışmada, nitel analiz yöntemlerinden içerik analizi yöntemi kullanılmıştır.

Çıkarsama esasına dayanan içerik analizi yöntemi, bir takım aşamalarda gerçekleşmektedir. Bu aşamalar; araştırma hedeflerinin belirlenmesi, örneklemin oluşturulması ve örneklemin bölüneceği birimler ve bunların içinde toplanacağı kategorilerin saptanması, kategori frekanslarının nicel olarak belirlenmesi, gerektiğinde 


\section{A. Yaşar - E. Çetin 12/1 (2020) 384-391}

kategoriler arasındaki ilişkilerin çözümlenmesi, değerlendirme, çıarsama ve yorumlama şeklinde olabilmektedir (Bilgin, 2014: 11).

$\mathrm{Bu}$ çerçevede, denetim raporlarında işletmenin sürekliliğine ilişkin önemli belirsizlik vurgusu yapılan 21 denetim görüşü içerik analizi yöntemiyle BDS 570 kapsamında incelenmiştir. Böylece, söz konusu denetim raporlarının iletişim değeri ile ilgili değerlendirme yapılmıştır.

\section{Araştırma Bulguları}

Örneklem kapsamındaki 21 şirketin 2018 yılı bağımsız denetim raporları iletişim değeri yönünden BDS 570 kapsamında içerik analizi yöntemiyle incelenmiştir². Söz konusu raporlar üzerinde yapılan inceleme sonucunda, elde edilen bulgular aşağıdaki Tablolarda belirtilmek suretiyle değerlendirmeler yapılmıştır.

\subsection{BDS 570 Kapsamındaki Denetim Görüşlerinin Sektörler İtibariyle Dağılımı}

BİST'de işlem gören örneklemdeki 21 şirkete BDS 570 kapsamında verilen denetim görüşleri ve sektörler itibariyle dağılımı Tablo 1'de yer almaktadır.

Tablo 1. BDS 570 Kapsamındaki Denetim Görüşlerinin Sektörler İtibariyle Dağılımı

\begin{tabular}{lcc}
\hline Sektör & Olumlu & Sinırlı Olumlu \\
\hline Gıda, İçki ve Tütün & 1 & 4 \\
\hline Metal Eşya, Makine ve Gereç Yapımı & 1 & 1 \\
\hline Spor, Eğlence ve Oyun Faaliyetleri & 0 & 4 \\
\hline Dokuma, Giyim Eşyası ve Deri & 0 & 2 \\
\hline Elektrik, Gaz ve Buhar & 0 & 1 \\
\hline Metal Ana Sanayi & 0 & 1 \\
\hline Güvenlik ve Soruşturma Faaliyetleri & 0 & 1 \\
\hline Taş ve Toprağa Dayalı & 1 & 0 \\
\hline Lokanta ve Oteller & 3 & 1 \\
\hline
\end{tabular}

Tablo 1'de görüldüğü üzere, işletmenin sürekliliğine ilişkin önemli belirsizlik içeren BDS 570 kapsamındaki denetim görüşlerinin 6 (\%29)'u olumlu; 15 (\%71)'i ise sinırlı olumlu denetim görüşü olarak verilmiştir. Tablo 2'deki denetim görüşlerine sektörler itibariyle bakıldığında; en çok Gıda, İçki ve Tütün Sektöründe verildiği görülmektedir. Ayrıca, sürekliliğe ilişkin önemli belirsizlik içeren olumlu denetim görüşünün en çok Lokanta ve Oteller sektöründe; sinırlı olumlu denetim görüşünün ise en çok Gıda, İçki ve Tütün sektörü ile Spor, Eğlence ve Oyun faaliyetleri sektöründe verildiği görülmektedir.

\subsection{BDS 570 Kapsamındaki Denetim Görüşlerinin Denetim Kuruluşları İtibariyle Dağılımı}

Örneklemdeki 21 şirkete BDS 570 kapsamında verilen denetim görüşleri ve denetim kuruluşları itibariyle dağılımı Tablo 2' de yer almaktadır.

Tablo 2. BDS 570 Kapsamındaki Denetim Görüşlerinin Denetim Kuruluşları İtibariyle Dağılımı

\begin{tabular}{|c|c|c|}
\hline Denetim Kuruluşu & Olumlu & Sinırlı Olumlu \\
\hline 4 Büyükler & 1 & 3 \\
\hline Uluslararası Diğer & 4 & 9 \\
\hline Ulusal & 1 & 3 \\
\hline TOPLAM & 6 & 15 \\
\hline
\end{tabular}

Tablo 2'de görüldüğü üzere, işletmenin sürekliliğine ilişkin önemli belirsizlik içeren BDS 570 kapsamındaki denetim görüşleri en çok Uluslararası Diğer denetim kuruluşlarınca verilmiştir. Tablo 2'de, işletmenin sürekliliğine ilişkin önemli belirsizlik içeren olumlu denetim görüşünün ve sınırlı olumlu denetim görüşünün en çok Uluslararası Diğer denetim kuruluşlarınca verildiği görülmektedir.

\footnotetext{
2 Şeffaflık ve denetçi raporlarının iletişim değeri kapsamındaki düzenlemelerin bir uzantısı olarak BDS 570'in son sürümü 24.03.2017'de yayımlandığından, en son yayımlanan 2018 şeffaflık raporları incelenmiştir.
} 


\subsection{BDS 570 Kapsamındaki Olumlu Denetim Görüşlerinin Denetçi Raporunda Açılanma Biçiminin İncelenmesi}

BDS 570 İşletmenin Sürekliliği Denetim Standartı'nın 24.03.2017 tarihli son sürümüne göre; finansal tablolarda önemli belirsizliğe ilişkin yeterli açıklamanın yapılması durumunda denetçinin olumlu görüş vermesi ve denetçi raporunda "İşletmenin Sürekliliğiyle İlgili Önemli Belirsizlik" başlı̆̆ı altında ayrı bir bölüme yer vermesi gerekmektedir (BDS 570, md. 22). Söz konusu standartta belirtilen bu hususun, denetçi raporlarındaki açıklanma biçimi, denetçi raporunun iletişim değeri açısından önem taşımaktadır. Bu kapsamda, BDS 570 kapsamında verilen 6 olumlu denetim görüşünün denetçi raporlarındaki açılanma şekli, söz konusu standart kapsamında incelenmiş ve denetim kuruluşları itibariyle Tablo 3'te yer verilmiştir.

Tablo 3. BDS 570 Kapsamındaki Olumlu Denetim Görüşlerinin Denetçi Raporunda Açıklanma Biçimi

\begin{tabular}{lcc}
\hline Denetim Kuruluşu & $\begin{array}{c}\text { İşletmenin } \\
\text { Sürekliliği ile } \\
\text { İlgili Önemli } \\
\text { Belirsizlik }\end{array}$ & Dikkat Çekilen Husus \\
\hline 4 Büyükler & 1 & 0 \\
\hline Uluslararası Diğer & 2 & 1 \\
\hline Ulusal & 0 & 3 \\
\hline
\end{tabular}

Tablo 3’te görüldüğü üzere, BDS 570 kapsamındaki olumlu denetim görüşlerinin 3'ü, söz konusu standarda uygun şekilde, "İşletmenin Sürekliliği ile İlgili Önemli Belirsizlik" başlığı altında ayrı bir bölümde açıklanmıştır. Denetçi raporunda bu şekilde açıklama, sadece 4 büyükler olarak adlandırılan denetim kuruluşlarınca yapılmıştır. Ancak, standart kapsamında verilen 3 olumlu denetim görüşünün ise "Dikkat Çekilen Husus" başlığı altında, üçüncü bölüm olarak açıklandığı görülmektedir. Bu kapsamda, olumlu denetim görüşünün 2'sinin uluslararası diğer denetim kuruluşu, 1'inin ise ulusal denetim kuruluşu olduğu görülmektedir. Bu tür açıklanma biçimi, söz konusu standart yoluyla aslında sağlanmak istenen denetçi raporunun iletişim değeri yönünden zayıflık oluşturabilecektir. Özellikle, olumlu denetim görüşlerinin görüş bölümü ile görüşün dayanağı bölümünün olumlu durumu yansıtan açıklamalar içerdiği göz önüne alındığında, işletmenin sürekliliği ile ilgili önemli belirsizlik başlığı altında ayrı bir bölümdeki açıklamanın önemi daha belirgin hale gelmektedir. Diğer taraftan, BDS 706 Bağımsız Denetçi Raporunda Yer Alan Dikkat Çekilen Hususlar ve Diğer Hususlar Paragrafları standardında (Paragraf A7); Dikkat Çekilen Hususlar paragrafının BDS 570'e uygun olarak yapılan raporlamanın yerini almayacağı belirtilmiştir. Dolayısıyla, BDS 570 kapsamındaki olumlu denetçi raporunda "İşletmenin Sürekliliğiyle İlgili Önemli Belirsizlik" başlığı altında ayrı bir bölüme yer verilmeyip, farklı bölüm veya başlıklar altında açıklama yapılması, şeffaflığı ve buna bağlı olarak da denetçi raporunun iletişim değerini zayıflatabilecektir.

\subsection{BDS 570 Kapsamındaki Stnırlı Olumlu (Şartlı) Denetim Görüşlerinin Denetçi Raporunda Açıklanma Biçiminin} Incelenmesi

BDS 570 İşletmenin Sürekliliği Denetim Standardında; finansal tablolarda önemli belirsizliğe ilişkin yeterli açıklamanın yapılmaması durumunda denetçinin BDS 705, uyarınca sınırlı olumlu görüş veya olumsuz görüşten uygun olanı verecektir. Bu durumda, denetçi raporunun Sınırlı Olumlu (veya Olumsuz) Görüşün Dayanağı bölümünde gerekli açıklamanın yapılması gerekmektedir (BDS 570, md. 23). Bu kapsamda, BDS 570 kapsamında verilen 15 sinırlı olumlu (şartlı) denetim görüşünün denetçi raporlarındaki açıklanma şekli, söz konusu standart kapsamında incelenmiş ve denetim kuruluşları itibariyle Tablo 4 'te yer verilmiştir. 
Tablo 4. BDS 570 Kapsamındaki Sınırlı Olumlu Denetim Görüşlerinin Denetçi Raporunda Açıklanma Biçimi

\begin{tabular}{|c|c|c|c|c|}
\hline Denetim Kuruluşu & 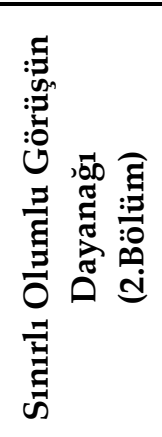 & 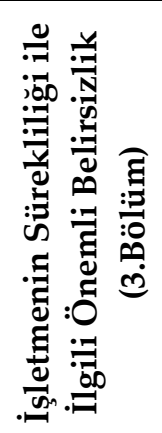 & 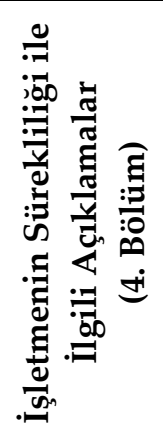 & 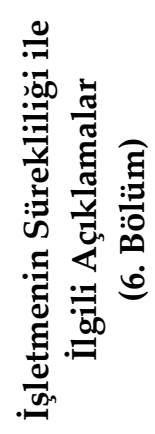 \\
\hline 4 Büyükler & 0 & 3 & 0 & 0 \\
\hline Uluslararası Diğer & 3 & 5 & 1 & 0 \\
\hline Ulusal & 0 & 2 & 0 & 1 \\
\hline TOPLAM & 3 & 10 & 1 & 1 \\
\hline
\end{tabular}

Tablo 4'te görüldüğü üzere, BDS 570 kapsamındaki 15 sinırlı olumlu denetim görüşünden 3'ü, söz konusu standarda uygun şekilde, "Sınırlı Olumlu Görüşün Dayanağı" bölümünde açılanmıştır. Denetçi raporunda bu şekilde açıklama, sadece uluslararası diğer denetim kuruluşlarınca yapılmıștır. Ancak, standart kapsamında verilen diğer 12 sınırlı olumlu denetim görüşünün ise farklı bölümlerde ve başlıklarda verildiği görülmektedir. Buna göre; sınırlı olumlu denetim görüşlerinden 10'unun “İşletmenin Sürekliliği ile İlgili Önemli Belirsizlik" başlığı altında 3. bölüm olarak, 1'inin "İşletmenin Sürekliliği ile İlgili Açılamalar" başlığ1 altında 4. Bölüm olarak, 1'inin ise yine "İşletmenin Sürekliliği ile İlgili Açıklamalar" başlığı altında ancak 6. Bölüm olarak verildiği görülmektedir. Özellikle, denetçi raporunun son kısımlarına doğru (4. ve 6. Bölüm) verilen bu türde açılanma biçimi, olumlu denetim görüşünün açılanma biçiminde olduğu gibi şeffaflı̆̆ ve dolayısıyla da denetçi raporunun iletişim değerini zayıflatıcı yöndeki açıklamalar olarak değerlendirilebilir.

\section{Sonuç}

Denetim sonuçlarının şeffaf bir şekilde açıklanmasında önemli bir araç olan denetçi raporları, açıklanan hususların bilgi değeri ve güvenilirliği açısından, ilettiği bilgiler yönüyle iletişim değeri üzerinde olumlu etkiler sağlayabilmektedir. Denetçi raporlarının iletişim değerini arttırmaya yönelik olarak, ABD başta olmak üzere, ülkemizin de aralarında bulunduğu birçok ülkede denetim sonuçlarının raporlanmasına ilişkin ilaveler ve/veya değişiklikler yapılmıştır.

Bu çalışmada, işletmenin sürekliliğine ilişkin önemli belirsizlik vurgusu yapılan denetçi raporları, BDS 570 İşletmenin Sürekliliğ̆i Standardı kapsamında incelenmiş ve söz konusu denetim raporlarının iletişim değeri değerlendirilmiştir. Bu amaçla, BISTT'de 2018 yılında işlem gören mali sektör şirketleri dışındaki şirketlerin bağımsız denetim raporları incelenmiştir. Yapılan incelemede, BDS 570 kapsamında işletmenin sürekliliğine ilişkin belirsizlik vurgusu yapılan 21 şirket belirlenmiştir. Söz konusu şirketlerin 6'sına olumlu; 15'ine ise sınırlı olumlu (şartlı) görüş verildiği tespit edilmiştir.

BDS 570 kapsamında işletmenin sürekliliğine ilişkin belirsizlik vurgusu yapılan örneklemdeki şirketlerin denetim raporları; sektör, denetim görüşü, denetim kuruluşu ve açıklanma biçimi yönünden sınıflandırılmıştır. Buna göre; BDS 570 kapsamındaki denetim görüşlerinin 6 (\%29)'sının olumlu; 15 (\%71)'inin ise sınırlı olumlu denetim görüşü yönünde verildiği görülmüştür. Ayrıca, olumlu denetim görüşü, en çok Lokanta ve Oteller sektöründe; sinırlı olumlu denetim görüşü ise en çok Gıda, İçki ve Tütün sektörü ile Spor, Eğlence ve Oyun faaliyetleri sektöründe verilmiştir.

BDS 570 kapsamındaki olumlu denetçi raporları incelendiğinde; “İşletmenin Sürekliliğiyle İlgili Önemli Belirsizlik" başlığı altında ayrı bir bölüme yer verilmeyip, farklı bölüm veya başlıklar altında açıklama yapıldığı görülmüştür. Dolayısıyla, BDS 570 kapsamındaki olumlu denetçi raporunda "İşletmenin Sürekliliğiyle İlgili Önemli Belirsizlik" başlığı altında ayrı bir bölüme yer verilmesi gerekirken, farklı bölüm veya başlıklar altında açılama yapılması, şeffaflığı ve buna bağlı olarak da denetçi raporunun iletişim değerini zayıflatabilecektir. 
A. Yaşar - E. Çetin 12/1 (2020) 384-391

Çalışmada, BDS 570 kapsamında verilen 15 sınırlı olumlu (şartlı) denetim görüşünün denetçi raporlarındaki açılanma şekli incelendiğinde; 3 denetim görüşü hariç, diğer 12 sınırlı olumlu denetim görüşünün ise standardın gösterim biçiminden farklı olarak, farklı bölümlerde ve başlıklarda verildiği belirlenmiştir. Dolayısıyla, tek bir yılın incelendiği bu çalışmada; BDS 570 kapsamında verilen olumlu denetim görüşünün açıklanma biçiminde olduğu gibi, sürekliliğe ilişkin önemli belirsizlik içeren sınırlı olumlu denetim görüşünün açıklanma biçiminin de, şeffaflı̆̆ sağlama ve dolayısıyla da denetçi raporunun iletişim değeri yönünden yeterli olmadığı yönünde değerlendirilmektedir.

\section{Kaynakça}

Akdoğan, N., Güdü, E.S, Işık, A., Sevinik, İ., Şahin, D. ve Özkan, G. (2018). 2014-2016 Yılları Arasında BísT Şirketleri ile İlgili Denetim Görüşleri, Muhasebe ve Denetime Bakış, 54, 1-18.

Bilgin, N. (2014). Sosyal Bilimlerde İçerik Analizi. 3. Baskı, Ankara, Siyasal Kitabevi.

Citron, D.B. ve Taffler, R.J. (1992). The Audit Report Under Going-Concern Uncertainties: An Empirical Analysis, Accounting and Business Research, 22(88), 337-345.

Çil Koçyiğit, S., Güngör Tanç, Ş. ve Elitaş B. L. (2018). İşletmenin Sürekliliği ve Bağımsız Denetçi Raporlarının Türkiye Bağımsız Denetim Standartları (BDS 570 ve BDS 700) Açısından İncelenmesi, Muhasebe ve Denetime Bakış Dergisi, 17 (53), 143-162.

Demirkol, Ö.F. (2019). BDS 570 İşletmenin Sürekliliği Standardının Uygulama Süreci ve Bağımsız Denetim Raporlarına Etkisi: BİST İnşaat ve Bayındırlık Sektöründe Uygulama, İşletme Araştırmaları Dergisi, 11(1), 478-489.

Karacan, S. ve Uygun, R. (2018). Kilit Denetim Konularının Bağımsız Denetçi Raporunda Bildirilmesi-BDS 701, Uluslararası Sosyal Araştırmalar Dergisi, 11(57), 632-649.

Kavut F. L. ve Güngör, N. (2018). Bağımsız Denetimde Kilit Denetim Konuları: BİST 100 Şirketlerinin 2017 Yılı Analizi, Muhasebe Enstitüsü Dergisi, 16(59), 59-70.

Sarısoy, Ö. ve Kepçe, N. (2019). Bağımsız Denetim Raporunda Kilit Denetim Konularına Yer Verilmesi ve Beklenti Farkları, Mali Çözüm Dergisi, 29(153), 39-66.

Sayar, A.R.Z. ve Ergüden, E. (2016). Son Düzenleme ve Gelişmeler Kapsamında Değişecek ve Yenilenecek Bağımsız Denetçi Raporları, Muhasebe ve Denetime Bakış, 48, 85-98.

T.C. Resmi Gazete (24 Mart 2017. Sayı: 30017). BDS 705 Bağımsız Denetçi Raporunda Olumlu Görüş Dışında Bir Görüş Verilmesi Standard1, www.resmigazete.gov.tr

T.C. Resmi Gazete (24 Mart 2017. Sayı: 30017). BDS 570 İşletmenin Sürekliliği Standardı, www.resmigazete.gov.tr

T.C. Resmi Gazete (09 Mart 2017. Sayı: 30002). BDS 706 Bağımsız Denetçi Raporunda Dikkat Çekilen Hususlar ve Diğer Hususlar Paragrafları Denetim Standard1, www.resmigazete.gov.tr

Taş, O., Mert, H., Güner, M. ve Duyar, G. (2018). BDS 570 İşletmenin Sürekliliği Standardının Denetim Raporlarına Etkisi, Press Academia Procedia, 7(1), 339-343.

Türel, A. ve Türel A. (2016). Yeni Denetim Raporlarının Finansal İletişime Etkileri, Seçmeler 2016, 101-116, İstanbul Üniversitesi İşletme Fakültesi Muhasebe Enstitüsü, Yayın No: 75, İstanbul, 2016.

Uzay, Ş. ve Tanç, Ş.G. (2009). İMKB'de İşlem Gören Şirketlerin Bağımsız Denetim Raporlarında İşletmenin Sürekliliği Kavramını Analizi, Muhasebe Bilim Dünyası Dergisi, 12(2), 143-179.

Yanık, S. ve Karataş, M. (2017). Denetim Raporlarının Geleceği: Yeni Düzenlemeler ve Ülke Uygulamaları, Muhasebe ve Finansman Dergisi, 73, 1-26.

Yılmaz, Z. ve Yaşar, A. (2018). Bağımsız Denetim Raporlarının İşletmenin Sürekliliği Denetim Standardı 570 Çerçevesinde İncelenmesi: BİST İmalat Sanayi Şirketleri Üzerine Bir Araştırma, Mali Çözüm Dergisi, 28(145), 55-90. 